Available online at: http:// http://tsdr.psdku.unpad.ac.id

Tourism and Sustainable Development Review Journal (TSDR)

ISSN 2722-2152 (online)

Volume 1 Number 2 (2020): 103-118

\title{
A Qualitative Case Study of Japanese Long-Stay to a Knot of New Wave Issues of Multiracial Thai-Japanese in Thailand
}

\author{
Thanapum Limsiritong1, Tomoyuki Furutani ${ }^{1}$, Karnjira Limsiritong 2 \\ ${ }^{1}$ Graduate School of Media and Governance, Keio University, Japan \\ 2 Doctorol program of Business Administration's, Siam University, Thailand
}

\begin{abstract}
Japanese long-stay in Thailand has been increased according to economic agreements; meanwhile, there is no data in the official report to second-generation as Thai-Japanese multiracial groups in Thailand. These two groups could be related number of increases because of family relationship reasons. According to developed countries, dismissing this relationship impact could because of racism, nationality, and tourism development issues. This research aimed (1) to study the impact of Japanese long-stay in Thailand (2) to study the current situation from Japanese long-stay tourist and Thai-Japanese multiracial in Thailand (3) to explore the elements of development dimensions from Japanese long-stay tourist and Thai-Japanese multiracial. In-depth interview and Data triangulation were used to analyze the data of similarity and generation perspectives into the data-saturated interpretation. Bangkok (1st province choosing by Japanese) in addition to Japan Embassy Thailand 2018 from 4 Thai-Japanese interviewees, four people of multiracial person family (Japanese long stay or migrant: Japanese first generation) and four specialists with personal safety data in promise. The result showed the current situation of Japanese long-stay tourist and multicultural Thai-Japanese issues. Government image, Economic policy, Good educational system, and having a government long stay center which could develop to Thailand tourism. Multiracial issues could be prepared in legal multiracial nationality status, and support and encourage the education system to social units could decrease conflict situations. Lastly, an ability to hold two nationalities and passports, Family and relationship, and working environment and living freedom were the main decision making of multiracial Thai-Japanese to live in Thailand.
\end{abstract}

Keywords: Qualitative study; Japanese long-stay tourist; multiracial Thai-Japanese; Thailand

\section{INTRODUCTION}

This is an open access article under the CC-BY-NC license.

The international community would be the result of tourism development in every kind of human traveling, settlement, or transnationality. Diversity plays in the big picture of identity and social awareness, meanwhile being a better country development sector could play a huge role in inviting people. Developed and Developing country characteristics are differenced by economic status judging of the parts such as GDP, GNP, and standard income because it could show the actual country capability in the world society. Tourism policy both short term and long term mainly play a part in introducing and inviting to the tourist, which expected to the result of revisiting as possible as they can.

From the statistic, Thailand tourism has increased from 2010-2018 for 11 percent out of 25 percent share of Asia and the Pacific region in international tourist arrivals, which was top ten in the world (UNWTO,2019). Furthermore, the tourism industry in Thailand 2019 played to 17 percent of GDP in Thailand, and also the competitive ranking was 31 from 140 countries, which was in the 3rd place in South East Asia (World Economic Forum,2019). The main province was Corresponding author thanapoom13@gmail.com 
centralized to tourism city destinations, which were Bangkok, Phuket, Chon Buri, and Chiangmai. These reported to over 65 percent of Thailand's industrial income (Bank of Thailand,2019).

Meanwhile, tourism has been using to Thailand development benefits, the length of tourists stayed, and revisiting could be the most challenging part. Especially, Long term staying could benefit to the impact factors from top to down management in Thailand as same as other tourism countries in the world. FDA and SME or SME polices were used as a driving machine of the economy to invite foreign investment, which means from temporally visiting transforming to the long term of staying until permanent of living. One of the most important countries that invest in Thailand as an agreement and alliance of economic investment in Japan. The accumulative manufacturing base and enterprises from Japan indicated to 64 percent of FDI in Thailand, which was over 5,000 companies invested from Japan in Thailand (BOI Thailand report,2017). As a result, the main provinces of tourism in Thailand were the target of investment to the hub settlement base. For example, they have Japanese communities in Bangkok, Sriracha(Chon Buri), and Chiangmai. Precisely, Long stay tourism becomes a big part of country income and economical driving as well. The positive and negative management could bring an impact of changing in tourism country.

The relationship in using tourism mechanical and economic agreements was presented by having a TAT office in Tokyo in 1917, Osaka in 1986, and Fukuoka in 1992, while JNT0 in Thailand (Bangkok) started in 1976. As same as the diplomatic relationship between Thailand and Japan have started in 1887(Japan Embassy,2019).

Japanese long stay in Thailand started from international retirement to other countries in 1986 in addition to an aging society situation and pension system management in Japan crisis while Thailand started to accept with long term stay as an international agreement from Japan in 2001. Additionally, the group of long term stay at the present time could count on expatriate, Freeter, and Digital Nomad, which means the wider generations of Japanese would stay in Thailand as a longterm tourist or permanent resident as well. Moreover, even if there is no data of the second generation of multiracial Thai-Japanese group in Thailand in official, the increasing of long-stay tourists could increase the number of multiracial Thai-Japanese group in Thailand because of international marriage potential. According to this situation of future population, studying in this multiracial group could impact every part of challenging country development both Thailand and Japan because of identity and nationality also social awareness in terms of international community and diversity.

As a result of few studies and few statistical accessibilities in a government official, this research focused on this group's impact in a current situation related to long-stay tourism impact and the possibility of Thailand developments.

\section{Word definitions}

Short stay: Staying as a plan of a week or until not over 60 days in conditions

Long stay: Staying plan in 90 days not over or until one year and also calling for visa extension in the term of the long-stay visa.

Immigrant: Staying over five years and having a right to make a decision for Thai nationality or permanent resident. 
Tourism and Sustainable Development Review Journal (TSDR), Vol. 1 (2), 103-118

A qualitative case study of Japanese long-stay to a knot of new wave issues of multiracial Thai-Japanese in Thailand

Thanapum Limsiritong, Tomoyuki Furutani, Karnjira Limsiritong

Multiracial: Concerning or containing members of two different races from their father or mother in a different nationality. 'Hafu' is the meaning of multiracial in Japan or 'Luuk kruung' in Thai.

\section{Purpose of the study}

1. To study the impact of Japanese long-stay in Thailand.

2. To study the current situation from Japanese long-stay tourist and Thai-Japanese multiracial in Thailand.

3. To explore the elements of development dimensions from Japanese long-stay tourist and ThaiJapanese multiracial.

\section{LITERATURE REVIEW}

\section{Thailand tourism development to long-stay tourism factors}

The basic of tourism development in Thailand was based on (1) having infrastructure building needs, (2) tourism attractions, and (3) relax on policy to allow of inducing investments (Cheowtirakul, 1980). From these viewpoints, wide-raging economic and political stability could be the milestone to increase people migrate and travel to other countries (Gebremedhin, 2013). Tourism in Thailand situations possibly related to the top to down country development policy. Meanwhile, the tourism policy achievements in Thailand might not be succeeded in a long term strategies because of community, environment, and nationality population matter according to Kayako (2010) There was a discussion about Thailand tourism development factors which could affect to Thailand long-running situation both Thai and foreigner research academic. The research left a big question on Thailand tourism development (1) Is "Thai tradition" really a factor that promotes prostitution in tourism, particularly in Thailand? (2) Does pro-poor tourism really raise the standard of living of the poor? (3) What is the role and meaning of border and nationality status in the tourism industry in Thailand?

Furthermore, the trend and possibility of tourist transformed to migrant (in case of longstay revisiting as usual and permanent resident) could be achieved in the condition of (1) Minimizing the negative aspects of traveling and migration (2) Strengthening the positive effects of traveling and migration (3) Protecting migrants'(include long stay) rights and ensuring their wellbeing $(\mathrm{IOM}, 2016)$ as same as to the assumption analysis from Thai academic scholar studied to Japanese long stay at Chiangmai in Thailand. The result presented to the definition of Japanese long stay as a 'Lifestyle migration' with five factors of achievement in the tourism and long stay tourism development idea (1) Freedom from the disciplinary inflexible from Japanese society (2) A cheaper cost of living in Thailand (3) A good atmosphere (4) Thai people seemed to be more open to Japanese cultural and easy to adjust in Thai culture (5)The ability to get supporting with Japanese support groups, agencies, and embassy (Sutpratana., D, 2015). Moreover, Thai living culture has been a mainstream absorption for Japanese long-stay and migrant in a preferred aspect of a relaxed lifestyle as we have known in Thai words called "Sabai-Sabai: It is ok ... don't worry" and having a lot of social opinions which were the opposite side with Japanese living culture such as strict rules but compromising. This cultural explanation showed a small mechanism part, but significant effective to Japanese people emigrated themselves to Thailand (Sadoshima,2018). However, the living style could explain in some reason factors that impact to Japanese long stay in Thailand while 
the perspective of new cultural acceptance was depended on individual background. Specifically, masculine culture could be defined to Japanese culture which had a different level of hierarchy and fairness, and feminine culture could be defined to Thai culture which had a collectivism dimension of groups acceptance and relationships (Thovuttikul.S,2018)

To develop tourism structure needs the basis of understanding to human needs (Papademetriou, D.2011). To be able to achieve that goal of development, Top to down policy, well manage governance, and economic stability becomes the main part of the country attraction (Siripen,2014). Furthermore, Understanding the deep studies of tourism development factors, expanding from short term to long term tourism needs to understand the pro and cons of what we have? What could affect levels of living and local? And using those factors to shape the society and encouragement people to accept and open to a diversity society(Resinger.,Turner.2011). In another way, the more tourism country development in positive factors are significant to country reputation and nationality credibility as well.

\section{Japanese long-stay tourism in Thailand to next-generation wave}

Economic expansion and relationship have been using as a representative of Japanese enterprises in many regions. Entrusting economic stability has brought Japan the potential to centralize the value of the economy. After the first Olympic game in Japan 1964, country sectors had been improved and escalated a huge step. One of the most significant development was Japanese disciplinary and behavior uniqueness. It becomes a picture of Japanese reputation nowadays.

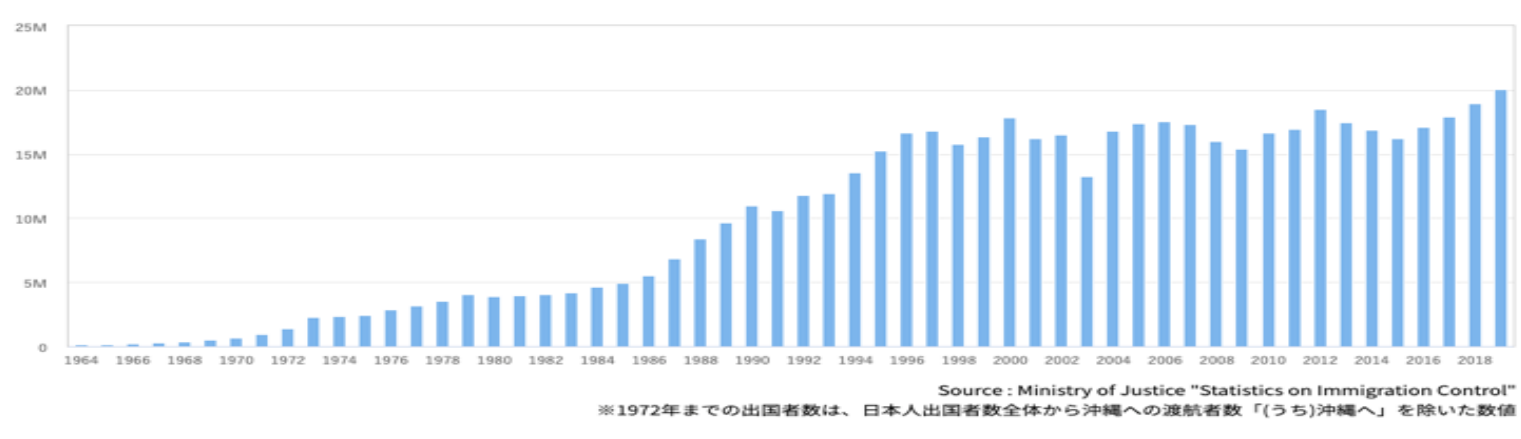

Figure 1. Japan residents'/Japanese visits abroad 2020, JTB Tourism statistics

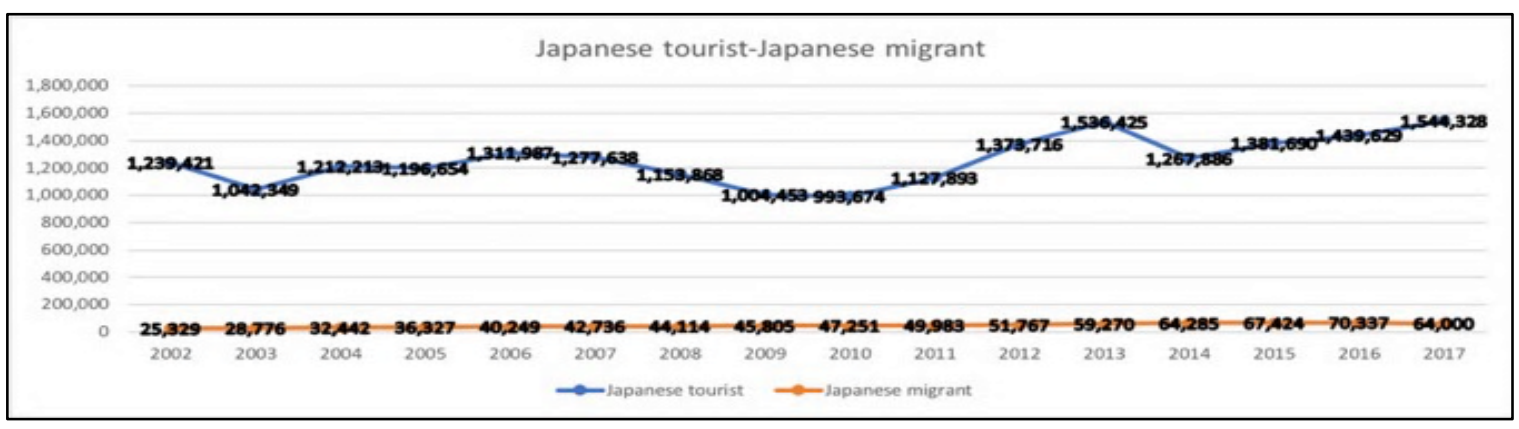

Figure 2. Japanese tourist / Japanese migrant statistic 2018, Japan Embassy in Thailand 
According to the statistic of Japan residents' and Japanese visits abroad from $1964-2018$, compared with the statistic from the Japan embassy in Thailand presented to the growing rate of Japanese ability to visit or stay abroad in the same way significantly. As same as with BOI Thailand 2018, Japan was the first place that invested in FDI in Thailand for over 20 years. There was 69 percent in the FDI investment from Japan. Especially, automobile production electronic and digital IT was the first category of investment. Owing to the economic current situation, skilled labor migrants from the headquarter in Japan would be increased as a long stay in Thailand.

In 1986, international retirement used to be one policy of Japan government because of the aging society crisis, which was the starting point of Japanese retirement at Chiangmai in Thailand. As a consequence, there are Japanese long-stay clubs, agencies, and Japanese in the Chiangmai association. Nursing care facilities in Japan, both the public and private sectors, were fully occupied. It becomes the first reason for Japanese international retirement moved abroad (Miyami.,ONO,2010) and support to the policy of the medical treatment hub of South East Asia in Thailand as well. On the contrary, there would be two sides effect of positive and negative according to medical resources, and treatment cost could be limited to Thai citizen who could reach to the conflict situation between long stay (migrant) and local (Naranong., Anchana, 2011)

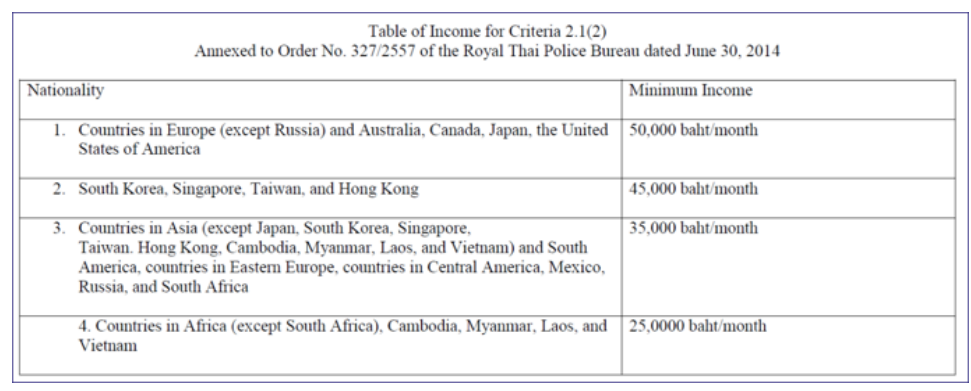

Figure 3. Table of minimum income in Law announced by Ministry of labor Thailand and the Royal Thai Police Bureau 2014

Income benefit guarantee for Japanese skilled labor in Thailand, which was higher than the Thai bachelor's degree minimum wage $(18,000 \mathrm{THB})$ for almost three times.

As a result, the Japanese could have a lot of benefits in Thailand as an expatriate, Freeter, and Digital nomad. The trend of Japanese living in Thailand has been broadening into generations, and the increasing number could support to the increasing number of international marriages in Thailand. Meanwhile, there is a study of Japanese impact on Thailand in many sectors. There are very few studies of second-generation Thai-Japanese multiracial, which could possibly affect the developed countries in the future.

\section{Nationality issues in Thai-Japanese multiracial in Japan and Thailand}

In the process of transforming the country from developing to a developed country, there is one big challenge situation of the multiracial situation. The result of this situation could impact mostly in (Supang,2014) negative part of political, workplace, rights, society, and country structural 
system. Racism, social discrimination could be the first notice of conflicts. For example, black and white people in the USA. or Asian Americans in the USA school problem.

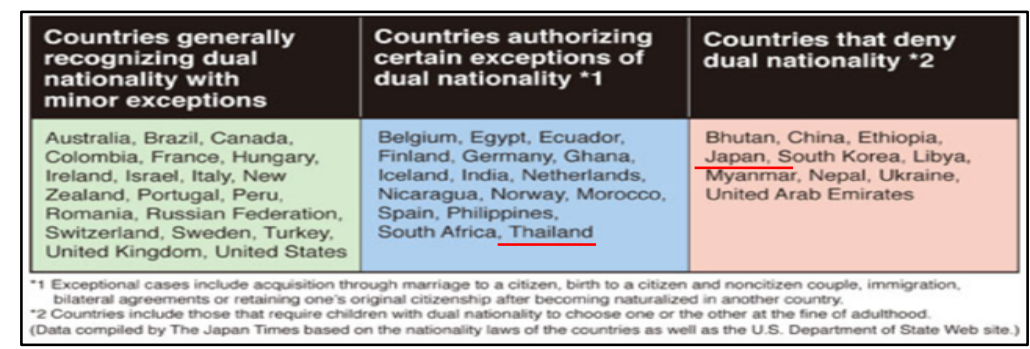

Figure 4. Dual nationality permission country, Harriet Cann (MAP: Dual citizenship around the world)

Japan denies for dual nationality according to the governance concept referencing to the WWII decade in 1945 (Kondo, 2016). Naturalization issues have been played to Japan nationality act over seven decades, although at the present time, Japan becomes a diversity in the world of globalization. International migrant labor has been invited in Japan for developing country infrastructure and fulfills the gap of population labor nowadays because of population balancing, low birth rate, aging society situation, and pension system breaking down. On the contrary, multiracial half Japanese in the media seemed to be a more positive attitude in commercial media and people attraction (Mori., KAORI, 2016); meanwhile, the law regulation was in the blind zone contradiction. For example, In the current situation 2018 of Naomi Osaka, half Japanese-Haitian American who was ranked in a 7th place tennis in the world at the age of 20 years old, "Are you Japanese enough?" was questioned by media and government. According to this current situation, the problem of nationality could impact to the country directly.

Nationality becomes an important role in after of long-stay tourist changing to permanent resident or citizenship and also directly authority of decision making in Japanese multiracial in Japan. The nationality act in Japan is not allowed people to have dual nationalities; the person who holds two nationalities has to choose only one at the age of 22 years old.
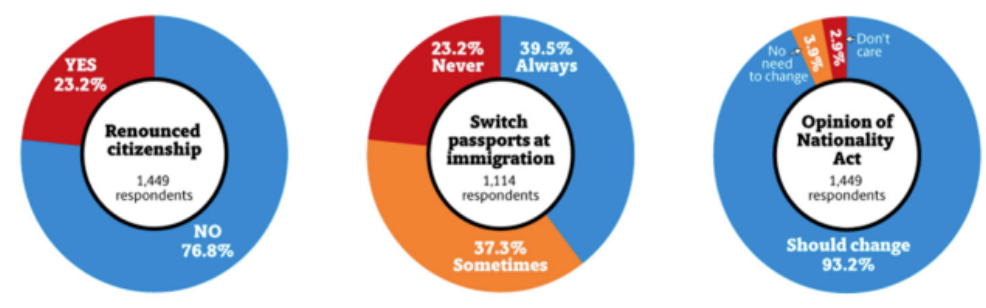

Figure 5. Surveying on Japanese dual citizenship (Japan Times :2019) 
Japan Times (2019) survey reported from 1,449 multiracial Japanese (Hafu) respondents in Japan, $76.8 \%$ would not renounce their citizenship, $73.8 \%$ switching passports at immigration, which means using for two passports, and $93.2 \%$ wanted to change nationality act.

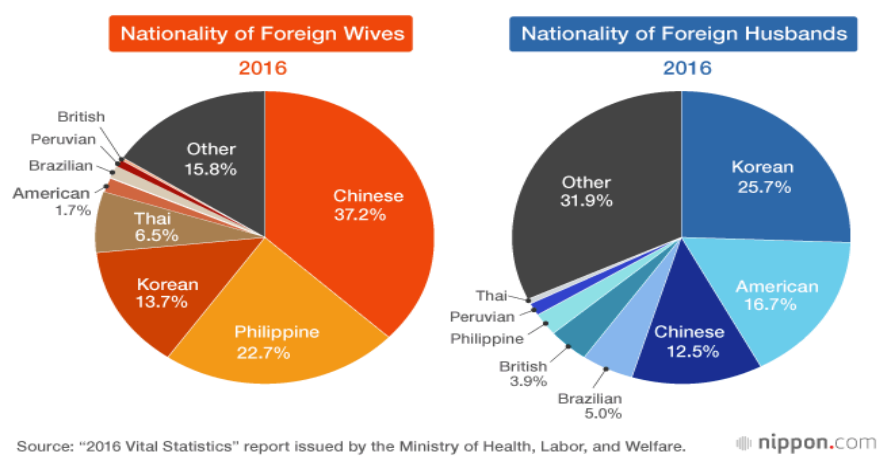

Figure 6. (2016 Vital Statistic): Thai nationality as Foreign Wives/Husbands in Japan

From the international marriage statistic 2016, Thai women tended to marry Japanese more than men in Japan, Thai nationality still joined in the majority part of international marriage in Japan. The number of Thai-Japanese could be increased in the future from the statistic. The wide gap of study in this nationality impact and resolution should be addressed in Thailand as same as a developed country having the problems previously.

\section{RESEARCH METHOD}

This research was conducted in qualitative research. In-depth Interviews with semistricture with data triangulation were used as a technique to collect the data.

\section{Population and area of collecting the data}

According to the statistic of Japanese long stay who lived in Bangkok for 53,000 people (from 73,000 people in total) which accumulated to $72.6 \%$ as the bigeest majority. However, this study had a purpose to understanding deeply by using a qualitative approach. Individual network contact was considered as a way to acquire a sampling data.

\section{Sampling selection}

Purposive sampling was used to set the criteria of sampling data for Thai-Japanese multiracial in Thailand who,

1. Having aged over 18 years old.

2. Having a dual nationality (Thai-Japanese).

3. Having an ability to communicate in Thai and English.

4. Having a residence in both Thailand and Japan.

5. Having experience in a time moment of individual purposes in Japan. 
Data collecting from 4 Thai-Japanese multiracial and using the personal contact network to collect 4 Japanese multiracial families (Japanese long stay or migrant 1st generation) were chosen in this qualitative research in the permission of in-depth interviews with the safety of revealing their personal data. Furthermore, the in-depth interview with 4 people specialists from Japanese media in Thailand, Japanese long-stay business agency owner in Thailand, scholar in migration management field, and a person from project management of human development in international organization.

Data Triangulation (4 of Multiracial Thai-Japanese/ 4 of Japanese long stay or migrant(first generation) of Thai-Japanese multiracial family / and 4 of specialists in related field) was used to check on the similarity, and difference data results with saturation data in control.

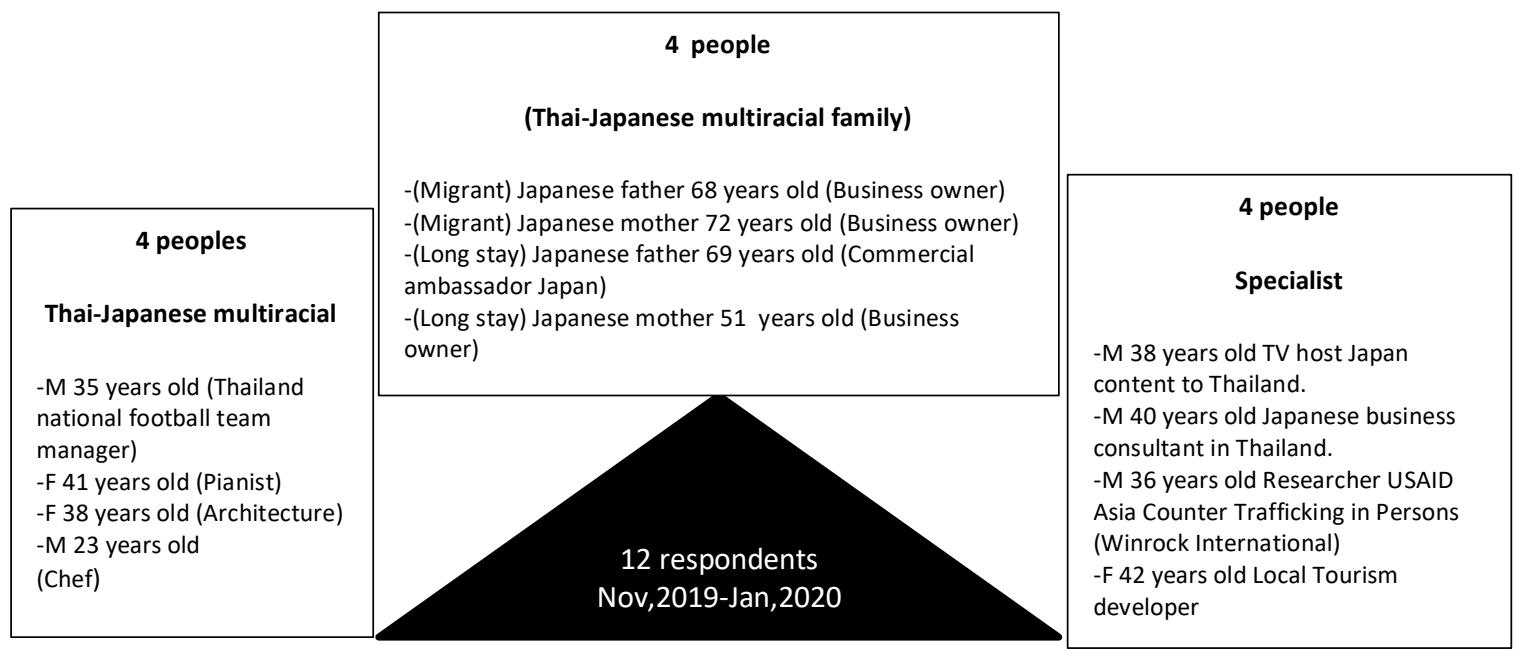

Figure 7. Data Triangulation

\section{Tools for data collecting}

An in-depth interview with semi-structured was used to acquire the data. There were three parts of the interview with demographic data, traveling background information, the opinion of Political and Governance / Economy / Working / Society and Cultural / Hospital and Treatment / and Country problems, and developments that reflect from their experiences until getting the data saturation. Furthermore, development solutions are brought to discuss in dimensions. 


\section{FINDINGS AND DISCUSSION}

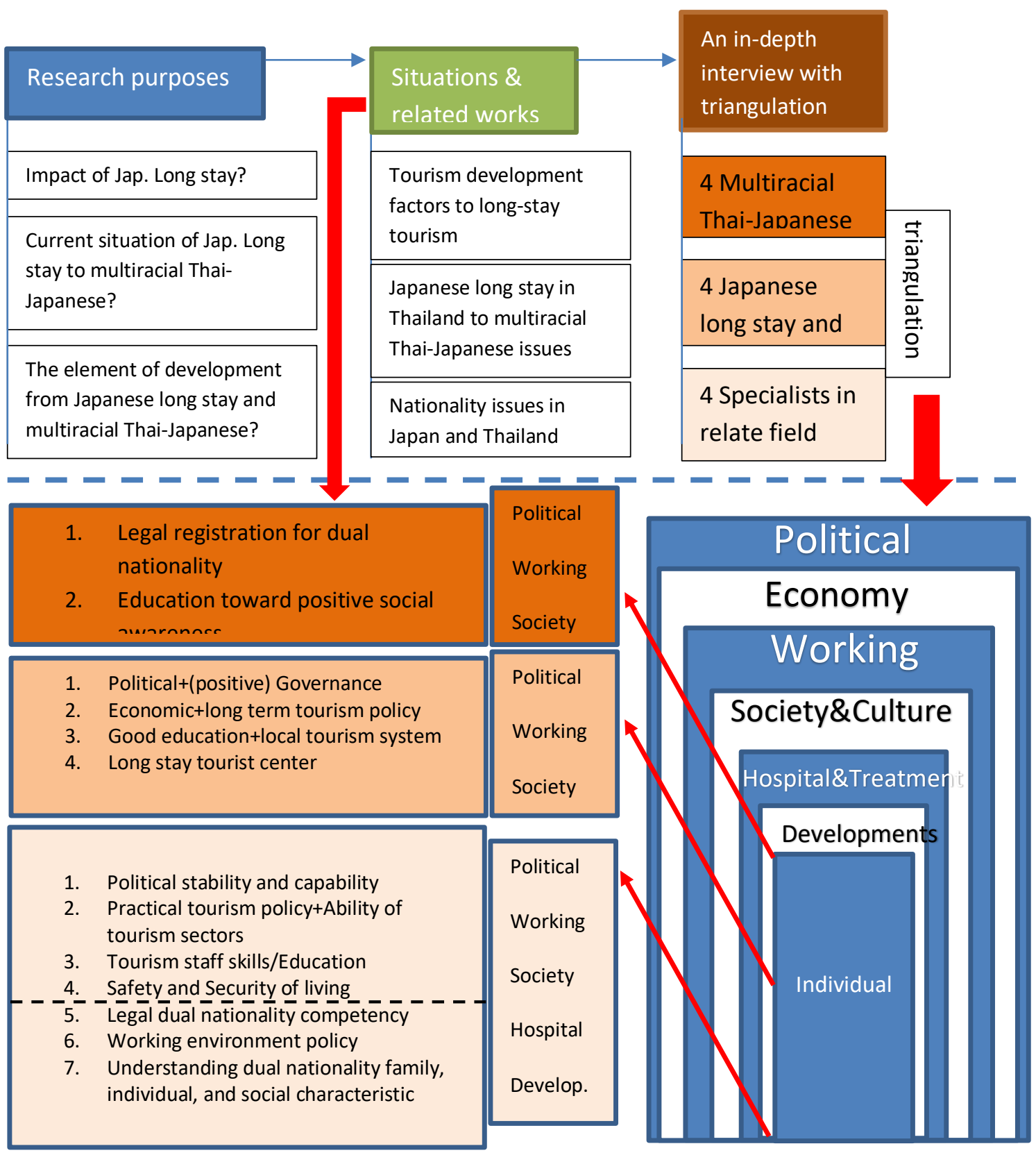

Figure 8. Data transformation to validation

Data transformation to validation shows to Political is the main major toward the economy, the environmental policy of working, society and culture, safety and security, and developments to people. Data saturation validates in terms of long-stay tourism to a challenging issue of multiracial Thai-Japanese in Thailand who relates to the number of Japanese long stays and migrants. This situation should be addressed in a new situation of future nationality population under the 
enhancing capability contexts of structural management toward policy to long-stay tourism (first generation) and multiracial (second generation).

The current situation of Japanese long stay and multiracial Thai-Japanese in Thailand are explained in the Taxonomy table of domain analysis. The results show the big problem of PoliticalGovernance and Economy structure in the negative perspective. On the other hand, a Business startup could be the potential of Thailand's long stay development. Moreover, working management in Thailand needs the system to manage to the people while the competitive awareness of Thai local and multiracial Thai-Japanese/foreigner could become a racism conflict issue in addressing to others as second class citizenship. Likewise, Society and Cultural shows to social responsibility should be more concerned with Thai daily life, and also, the negative impact of the Thai prostitution image is the stereotype perceived problem that government should find the way to adjust the attitude from inbound to outbound Thailand tourism. Furthermore, most of the interviewees prefer to have a medical treatment in the private hospital because of the serviced standard and quality of medical resources such as Samitivej Hospital (Japanese sectional), Bumrungraj Hospital (Japanese translator) even if it is much more expensive than a private hospital. Accessibility of private hospitals from the interviewees should concern people in every class, especially grass root people medical treatment. Lastly, Country problems and developments show that safety and security management and also Public services from the government are the bad factor for living in Thailand, definitely having a direct impact on the daily life of local people and every type of tourist because of the transportations problems and high rate of crimes.

Table 1. Thailand tourism current situation issues in Taxonomy table

\begin{tabular}{|c|c|c|}
\hline Domain & Categories & $\begin{array}{l}\text { Sub-categories Triangulation interviewing conclusion } \\
\text { Points saturated }\end{array}$ \\
\hline \multirow[t]{3}{*}{$\begin{array}{l}\text { 1. Political - } \\
\text { Governance }\end{array}$} & Structural & $\begin{array}{l}\text {-Policy Corruption impacts on the policy process and } \\
\text { to governance: governance system could not run to } \\
\text { the development and social units. }\end{array}$ \\
\hline & $\begin{array}{l}\text { Law } \\
\text { enforcement }\end{array}$ & $\begin{array}{l}\text {-Corruption: Whole public system corruption. } \\
\text {-Officer quality: Officer lacks knowledge of using law. } \\
\text {-Safety protocol: Low trusted and quality of measurements. }\end{array}$ \\
\hline & Situation & $\begin{array}{l}\text {-Dictatorship: Negative image and reputation of Thailand. } \\
\text {-Bureaucracy: Slow process, using a possible alternative. } \\
\text {-Leader ability: Without the capability of management. }\end{array}$ \\
\hline 2. Economy & Management & $\begin{array}{l}\text {-Business start-up: Easy to have a business and procedure. } \\
\text {-High tax payment: Foreigner tax income and business are } \\
\text { very high which make more on } \\
\text { financial statement manipulation and } \\
\text { do not want to pay because of the lack } \\
\text { of developments. }\end{array}$ \\
\hline
\end{tabular}


Tourism and Sustainable Development Review Journal (TSDR), Vol. 1 (2), 103-118

A qualitative case study of Japanese long-stay to a knot of new wave issues of multiracial Thai-Japanese in

Thailand

Thanapum Limsiritong, Tomoyuki Furutani, Karnjira Limsiritong

\begin{tabular}{|c|c|c|}
\hline Domain & Categories & $\begin{array}{l}\text { Sub-categories Triangulation interviewing conclusion } \\
\text { Points saturated }\end{array}$ \\
\hline \multirow[b]{2}{*}{ 3.Working } & $\begin{array}{l}\text { Class of } \\
\text { Income }\end{array}$ & $\begin{array}{l}\text {-Salary: Low salary for an average of the minimum wage. } \\
\text {-Living cost: Tourism city is expensive as the same as Tokyo. } \\
\text { Bangkok is the most expensive to live if } \\
\text { compares to other cities in Thailand } \\
\text { respectively. } \\
\text {-Social class: Thailand has a very wide social class, } \\
\text { the government should full fill the gap by } \\
\text { occupation and social standard accessibility. }\end{array}$ \\
\hline & Environment & $\begin{array}{l}\text {-Relaxed way As a half Thai-Japanese, working here is } \\
\text { of working: much more relaxed than in Japan. } \\
\text {-Flexibility: Too much flexibility of Thai discipline. } \\
\text {-Gender equality: Better than in Japan, women could be } \\
\text { worked many positions in Thailand but } \\
\text { sometimes the second citizen of foreigner worker } \\
\text { could happen among Thai colleagues. } \\
\text {-Skilled exchange: Needs a system to make it in a better } \\
\text { standard, Thai way is about mouth to } \\
\text { mouth teaching }\end{array}$ \\
\hline \multirow[t]{3}{*}{$\begin{array}{l}\text { 4.Society and } \\
\text { Cultural }\end{array}$} & Lifestyle & $\begin{array}{l}\text {-A relaxed way } \\
\begin{array}{l}\text { of living: } \quad \text { Freedom to live in Thailand and nice } \\
\text { people. Living in Japan has too much rules. }\end{array}\end{array}$ \\
\hline & $\begin{array}{l}\text { Social } \\
\text { awareness }\end{array}$ & 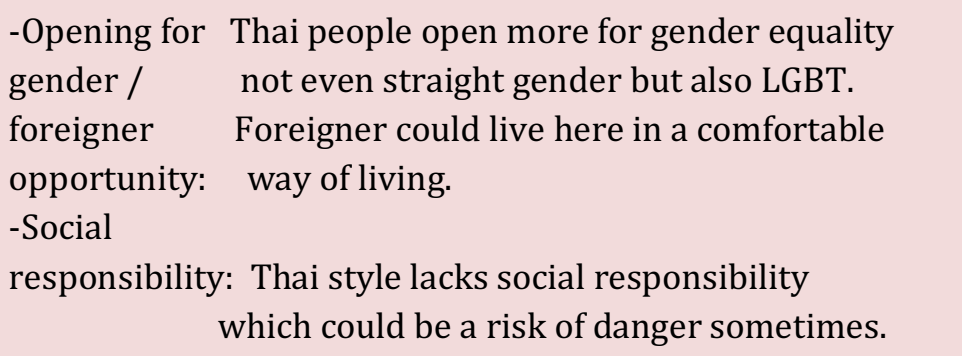 \\
\hline & $\begin{array}{l}\text { Personal } \\
\text { relationship }\end{array}$ & $\begin{array}{l}\text {-International } \\
\text { marriage: } \quad \text { Thai tourism should help to change the } \\
\text { attitude of Thai women in a positive way. } \\
\text {-Family: } \quad \text { Thai family is really care of family } \\
\quad \text { relationship, living together. }\end{array}$ \\
\hline $\begin{array}{l}\text { 5.Hospital and } \\
\text { Treatment }\end{array}$ & Accessibility & $\begin{array}{l}\text {-The number of } \\
\text { public/private: Hospital in Thailand is not enough } \\
\qquad \text { especially public hospitals. } \\
\text {-Private optional: Better choice because of service and }\end{array}$ \\
\hline
\end{tabular}


Tourism and Sustainable Development Review Journal (TSDR), Vol. 1 (2), 103-118

A qualitative case study of Japanese long-stay to a knot of new wave issues of multiracial Thai-Japanese in Thailand Thanapum Limsiritong, Tomoyuki Furutani, Karnjira Limsiritong

\begin{tabular}{|c|c|c|}
\hline Domain & Categories & $\begin{array}{l}\text { Sub-categories Triangulation interviewing conclusion } \\
\text { Points saturated }\end{array}$ \\
\hline & $\begin{array}{l}\text { Cost of } \\
\text { treatment }\end{array}$ & $\begin{array}{l}\text { quality but it is not cheap. } \\
\text {-Easy to get a } \\
\text { medicine in } \\
\text { a cheap price: } \quad \text { Cheap medicine price in Thailand. }\end{array}$ \\
\hline \multirow[t]{2}{*}{$\begin{array}{l}\text { 6.Country } \\
\text { problems and } \\
\text { developments }\end{array}$} & $\begin{array}{l}\text { Safety and } \\
\text { security } \\
\text { management }\end{array}$ & $\begin{array}{l}\text {-Transportation: Not safe in Thailand especially on the } \\
\text { pedestrian ways and traffic management. } \\
\text {-Pollution: Very bad management (PM2.5) } \\
\text {-Food hygiene: Be careful and choosing to eat wisely } \\
\text {-Crime/Theft/Drugs: Because of low income, } \\
\text { unemployment situation and wide } \\
\text { social class. It dangerous sometimes. }\end{array}$ \\
\hline & $\begin{array}{l}\text { Public } \\
\text { services } \\
\text { provided by } \\
\text { government }\end{array}$ & $\begin{array}{l}\text {-Elderly care: Not enough and few awareness of aging } \\
\text { society impact. } \\
\text {-Disability care: Not enough and a lot of disability becomes } \\
\text { stray homeless on the street. }\end{array}$ \\
\hline
\end{tabular}

According to an in-depth interview with semi-structure from 6 dimensions that could impact and benefit to Japanese Long stay tourism in Thailand and also multiracial Thai-Japanese as a future population situation.

The research resulted in 4 approaches of long-stay tourism development solutions from Japanese Long Stay with specialists in Thailand and two approaches of multiracial nationality development solutions from Multiracial Thai-Japanese with specialists in Thailand. Moreover, the decision making in the living of multiracial Thai-Japanese in Thailand was found for three main reasons.

There are four approaches to long-stay tourism development solution from Japanese Long Stay tourism with a specialist in Thailand.

Developing Political and Governance in a positive changing.

Evaluation and monitoring will be the way of adjusting from negative of corruption in the system to a positive attitude of management, respectively. Policies and measurement could affect to society units clearly. Government officers will be the actor of government reputation, training system, and using wireless network technology to operate the system with a quick and clear procedure to both local and foreigner in the same standard could lead the point of Government entrusted.

Economic policy should play a part in long-term tourism policy.

Economic policy has the potential to invite foreign investment. Economic inbound is very important to stabilize the country's economic status. If tourism promotion in Thailand tends to have more impact on GNP sharing products. Tourism policy in Thailand should research the inbound 
market needs and fulfill the gap by economic business start-up policy. The integration will be targeted from Long stay tourism, for example, Japanese restaurant, Japanese design, and architecture, all preserved occupations of Thai people should be considered to the alternative of foreign to be able to work in Thailand, such as Japanese hairstylist and barber or craftworks. Japanese Freeter and Digital nomad or professional workers will interest as Thailand's destination of new starting. Furthermore, ageless society could be the policy of supporting older people to work, which means tourism could be part of an aging society solution more than focusing on a traveling area.

A good educational system should encourage local area tourism.

Social awareness and languages should be included in the educational curriculum system. Tourism will be able to grow up if Thai citizen have an ability to communicate in a second language. Social units local will be developed in double supporting both outside and inside society capability. Even though tourism policies are trying to reduce the rate of the low-income area to be able to compete and tourism area development, it could not achieve if the social units could not understand and be able to strengthen the policies to the goals. Also, if tourism and education could integrate together to human development, capital concentration could spread out from urban to suburban as the same as Japanese long-stay persons and communities will broaden closer to Thai society units as well. Well, communication will reduce the conflict and the gap of social diversity.

Constructing of government long-stay tourist sector as a management center.

Long stay tourist management center should be addressed if Thailand tourism realized about long-stay tourism. At the present time, the management structure of long-stay tourism in Thailand does not have a concrete information center. The information has relied on the TAT, embassy, and private agencies, which is difficult to acquire the procedure. For example, if Japanese long-stay tourist motivates from the economy, Thailand government should centralize the supporting and information center to the target group purposes.

There are two approaches to multiracial nationality development solutions from Multiracial Thai-Japanese with a specialist in Thailand.

\section{Constructing of legal nationality of multiracial in Thailand.}

Government policy and nationality act have the ability to shape people's awareness and attitude. If Thailand is very clear of the purpose to let multiracial to stay or live, it is better to have the official announcement. Even if nationality is a big problem of population structure, the government should research and develop the idea of living in an international community. Estimating pro and con should be considered relates to labor, market, and population needs according to the example of an aging society and pension system failure in Japan. Supporting multiracial groups to live will support long-stay tourists importantly because family reason is the important reason for long-stay tourist and second generation to live together.

Educational support and encouragement.

A bottom-up attitude should be generated to social awareness. If the distancing of top to down policy is very wide, proactive policy educational provided could be the answer of social-based 
understanding in society and generations. The ability to communicate and social activities could be the tools to relieve the conflict. Especially, middle language or second language could bring local to the international community practically.

There are three main conclusions of specialists to multiracial Thai-Japanese and Japanese long stay in Thailand factors concerned which will support in longterm management (1) Ability to hold two nationalities and two passports, (2)Family and relationship reason, and (3) Working environment and living freedom.

\section{CONCLUSION}

The impact of the Japanese long-stay could raise the number of multiracial Thai-Japanese. The relationship between these two groups are definitely related. The effect of tourism policy and economic policy could direct effect on Japanese long stay and number while indirect effect to ThaiJapanese as well. Policymakers constructing the long-term strategies should realize the relationship and adding the second generation to the mechanism of factors that could affect tourism factors, nationality issues, and future population as well.

\section{LIMITATION \& FURTHER RESEARCH}

Quantitative research should be considered with the amount of data sampling in Exploratory factor analysis or SEM analysis. Having the factors in these issues could be an effective resolution for government approach, policymaker, and social understanding awareness.

\section{REFERENCES}

Bank of Thailand. (2019). Tourism statistic and indicators. Retrieved from https://www.bot.or.th/App/BTWS STAT/statistics/BOTWEBSTAT.aspx?reportID=875\&language $=\mathrm{ENG}$

BOI(Thailand Board of Investment). (2018). Annual Report 2018. Retrieved from

https://www.boi.go.th/index.php?page=annual_report\&language $=e n$

Burgess, C. (2007). Multicultural Japan? Discourse and the 'Myth' of Homogeneity. The Asia-Pacific Journal, 5(3), 1-25.

Cheowtirakul, C. (1980) A study factors attracting American tourists to Thailand. Doctoral dissertation submitted to the Graduate College of Texas A\&M University.

Gebremedhin, T. et al. (2013). Immigration and political stability. OECD. Discipline of economics. University of Canberra. Retrieved from

http://www.oecd.org/development/pgd/46923664.pdf

IOM. (2016). Measuring well-governed migration: The 2016 Migration Governance Index.

Retrieved from

https://publications.iom.int/system/files/pdf/migration governance index 2016.pdf Ishii, Kayako. (2010). Theories and Models on Thai Tourism. Japanese Journal of Human Geography, 62(6), 506-518. Retrieved from https://www.jstage.jst.go.jp/article/jihg/62/6/62 506/pdf?fbclid=IwAR2Rj3VTAVqGVbfAPhQI1 jIY8G2tRuCsiHrwKm-5uxVgyVNNH3tkOKGHdu8

JTB Tourism Research \& Consulting. (2020). Japan Residents'/Japanese visits abroad statistic. Retrieved from https://www.tourism.jp/en/tourism-database/stats/ Kondo, Atsushi. (2016). Report on citizenship law:Japan. European university institute. Italy 
Tourism and Sustainable Development Review Journal (TSDR), Vol. 1 (2), 103-118

A qualitative case study of Japanese long-stay to a knot of new wave issues of multiracial Thai-Japanese in Thailand

Thanapum Limsiritong, Tomoyuki Furutani, Karnjira Limsiritong

(11). Retrieved from

https://cadmus.eui.eu/bitstream/handle/1814/43625/EudoCit 2016 11Japan\%20.pdf?seque nce $=1 \&$ isAllowed $=y$

Murakami.,Sakura \& Baird., C. (2019). Dual citizenship in Japan : A “don't ask, don't tell”

policy leaves many in the dark. The Japan Times. Retrieved from

https://features.japantimes.co.jp/dualcitizenship/

NaRanong, Anchana \& NaRanong, Viroj. (2011). The effects of medical tourism: Thailand's experience. Bulletin of the World Health Organization, 89 (5), 336 - 344. World Health

Organization. http://dx.doi.org/10.2471/BLT.09.072249

Ono,Miyami. (2010). Long-stay Tourism : Elderly Japanese Tourists in the Cameron

Highlands, Malaysia. Senri Ethnological Studies. 76, 95-110

Papademetriou, D. (2011). The governance of international migration: Defining the potential

for reform in the next decade. Migration Policy Institute. Retrieved from

file:///Users/macintosh/Downloads/TCMStatement-IntlGovernance.pdf

Reisinger,Y. Turner,L. (2011). Cross-Cultural Behaviour in Tourism: Concepts and Analysis.

Taylor\&Francis. Retrieved from https://www.sciencedirect.com/book/9780750656689/crosscultural-behaviour-in-tourism\#book-description

Shiro Sadoshima. (2018). The past and future Thailand- Japan relationship (Japan ambassador in Thailand). Elite magazine. Retrieved from http://www.eliteplusmagazine.com/home/content/521/3\#gsc.tab $=0$

Siripen Yiamjanya. Wongleedee, K. (2014). International Toureists' Travel Motivation by

Push-Pull Factors and the Decision Making for Selecting Thailand as Destination Choice.

International Journal of Social, Behavioral, Educational, Economic, Business and Industrial

Engineering. 8(5). 1348-1353.

Supang Chantavanich. (2014). Thailand migration policy and populism. Asian research center for migration(Institute of Asian Studies). Retrieved from https://www.victoria.ac.nz/_data/assets/pdf file/0006/778929/supang-chantavanich.pdf

Sutasinee Thovuttikul et al. (2019). Comparison of influence of Thai and Japanese cultures on reasoning in social communication using simulated crowds. Journal of information and telecommunication. 3(1). 115-134. Retrieved from

https://doi.org/10.1080/24751839.2018.1537557.

Sutpratana Duangkaew. (2015). Lifestyle migration of Japanese: A case study of retired Japanese in Chiang Mai Province, Thailand. Jsn Journal. 5. 35-52.

Thailand Law Online. (2014). Foreign Employment Act: minimum wage. Retrieved from

https://www.thailandlawonline.com/thai-company-and-foreign-business-law/work-permit-forforeigners-in-thailand

United Nations Department of Economic and Social Affairs. International Migration Report

2017. Retrieved from

http://www.un.org/en/development/desa/population/migration/publications/migrationrep ort/docs/MigrationReport2017.pdf

UNWTO. (2019) International Tourism Highlights 2019. Retrieved from

https://www.e-unwto.org/doi/pdf/10.18111/9789284421152

Viager, A. (2011). Multiracial Identity Development: Understanding Choice of Racial 
Identity in Asian-White College Students. Journal of the Indiana university student personnel association. 38-45. Retrieved from

https://scholarworks.iu.edu/journals/index.php/jiuspa/article/view/1937/1913.

Want, Kaori Mori., (2016). "Haafu Identities Inside and Outside of Japanese

Advertisements." Asia Pacific Perspectives, Vol.13(2). 83-101.

World Economic Forum. (2019). The Travel \& Tourism Competitiveness Report 2019:

Travel and Tourism at a Tipping Point. Retrieved from

http://www3.weforum.org/docs/WEF_TTCR_2019.pdf 